\title{
Influence of Genotype on Protein and Oil Concentration of Soybean Seeds
}

\author{
Esmael Lopes dos Santos ${ }^{1 *}$, Antonio Eduardo Pípolo ${ }^{2}$, Ricardo Tadeu de Faria ${ }^{1}$ and Cássio \\ Egidio Cavenaghi Prete ${ }^{1}$ \\ ${ }^{1}$ Curso de Pós-Graduação em Agronomia; Universidade Estadual de Londrina; C. P.: 6001; 86051-990; Londrina - \\ PR - Brasil. ${ }^{2}$ Embrapa Soja; C. P.: 231; 86001-970; Londrina - PR - Brasil
}

\begin{abstract}
Aiming at evaluating genotype influence on the concentration of protein and oil, immature seeds of cultivars CD 202 and CD 206 were removed from the mother-plant, in the stage $R_{5}$, and were grown in vitro, in a liquid culture medium which contained 20, 40 and $60 \mathrm{mM}$ of glutamine, during eight days. Afterwards, the concentrations of oil and protein were compared to the contents of the seeds cultivated in vivo. With a higher availability of glutamine for the seed, there was an increase of protein content. The genotypes were statistically different as far as the protein concentration was concerned, which confirmed that the genotype had influence on the concentration of protein in the seed. Oil and protein concentrations were inversely related when a variation of glutamine concentration occurred.
\end{abstract}

Key words: Glutamine, fresh weight, seed composition, in vitro growth and Glycine max

\section{INTRODUCTION}

Soybean is produced aiming at fulfilling human and animal requirements for protein and oil. It is desirable that high productivity may be accompanied by a high concentration of those components, since it involves the reduction of costs of soybean by-products (Tanaka et al., 1995; Marega Filho et al., 2001). Improving the production potential of soybean cultivars is one of the main objectives of all genetic improvement programs carried out in the country. In general, soybean productivity is inversely correlated to the protein content of grains (Voldeng et al., 1997; Wilcox and Guodong, 1997).

Protein and oil concentrations in the seed may be genetically controlled but those components are highly influenced by the environment (Wilcox, 1985; Burton, 1989). The obstacle to increase the protein and oil contents of commercial cultivars is the inverse and consistent relationship among the productivity, protein concentration and the negative correlation between protein and oil concentration in the soybean seeds (Burton, 1985). There are evidences that the growth and composition of soybean seeds are controlled by the quantity of nutrients, made available by the genetic of the mother plant or by the environment. Therefore, controlled cultivation in vitro of seeds allows studying the factors that regulate seed's growth and composition in the absence of interaction with the mother plant. Thompson et al. (1977) and Obendorf et al. (1984) have described the success obtained with soybean seeds cultured in situ and in vitro. Those studies represented a major advance to understand the development of soybean seeds in vitro, including: 1) estimates on the effect of temperature on the seed's growth rate

\footnotetext{
*Author for correspondence: esmael@ fapeagro.org.br
} 
(Egli and Wardlaw, 1980; Pípolo et al., 2004a); 2) the relationship among genetic differences, seed's growth rate and the numbers of cotyledon cells (Egli et al., 1981); 3) synthesis of storage protein (Madison et al., 1981); 4) use of ureids, amid and amino acids for the synthesis of protein in soybean immature cotyledons (Thompson et al., 1981; Rainbird et al., 1984; Holowash et al., 1984; Haga and Sodek, 1987; Wettlaufer and Obendorf, 1991); 5 ) growing and composition rates of soybean seeds affected by the supply of carbohydrate and/or nitrogen assimilated by the seed (Saravitz and Raper, 1995, Hayati et al., 1996; Pípolo et al., 2004b).

Obendorf et al. (1984) also demonstrated that, provided with a simple set of materials, the soybean seeds grew regularly. Sucrose is the primary way to carbohydrate translocation and it plays an essential role in carbon partition for the synthesis of protein and oil (Smith et al., 1989).

Thompson et al. (1977) observed that glutamine in the concentration of $31,62.5$ and $125 \mathrm{mM}$ was not effective for the accumulation of dry matter in soybean cotyledons cultivated in vitro, but the highest concentration of protein occurred in 62 $\mathrm{mM}$. Pípolo et al. (2004b) studied the influence of increasing glutamine concentration for the accumulation of protein and oil in soybean seeds. The authors suggested that the protein synthesis of the seeds increased whenever a higher availability of glutamine occurred, while the oil and protein accumulation are inversely related when there was a variation in the glutamine concentration. Furthermore, the results showed a negative relationship between the concentration of protein and oil, due to the balance of carbon and nitrogen made available to the seed. The purpose of this study was to investigate the influence of genotypes on the protein and oil concentration in soybean seeds.

\section{MATERIAL AND METHODS}

\section{Source of young seeds}

Soybean cultivars were selected from those with high and low contents of protein and oil, according to the results published by Oliveira et al. (2004), as follows: cv. CD 202 (CEPSD 77-16 X Invicta) with $36.45 \%$ of protein ${ }^{1}$ and $22.72 \%$ of oil and CD 206 (OC 87-5085 X FT Abyara) with $40.56 \%$ of protein $^{1}$ and $22.10 \%$ of oil. The plants were grown in a greenhouse in ceramic pots with two plants per pot. Sowing took place at 15 days intervals so that the continuous supply of immature seeds for the experiments were guaranteed.

The pots were prepared with soil removed from 2 $m$ depth and fertilized in accordance with the analysis of the soil and the culture's requirements. Pods containing three seeds were removed from the medium third of the plant, three to five weeks after flowering (linear phase of the seeds growth) and when viewed against the light, the pods were completely elongated and the seeds filled about $70-90 \%$ of the pod lumen (stage $\mathrm{R}_{5}$ ). The seeds at stage $R_{5}$ were submitted to development in vitro during eight days. By the end of that period, both the seeds from the medium third of the pods, and the seeds developed in vitro were harvested to determine the protein and oil contents.

\section{In vitro culture conditions}

The conditions of cultivation in vitro were those described by Pípolo et al. (2004b). According to Oberdorf and Wettlaufer (1984) to prevent the precocious germination the sucrose concentration was $204.5 \mathrm{mM}$. Stocking solutions of culture mediums were previously prepared without sucrose, mio-Inositol and glutamine. On the day of the experiment, the sucrose and mio-Inositol were added to the solution. The culture medium ( 8.0 $\mathrm{mL}$, without glutamine) was were put in each flask which was covered and autoclaved at $121^{\circ} \mathrm{C}$ and 18 PSI for 15 min.

After cooling this was supplemented with $4 \mathrm{ml}$ of autoclaved distilled water in each flask. Glutamine was sterilized by means of ultra-filtering and the added at 20, 40 and $60 \mathrm{mM}$. The treatments were conducted by incubating the seeds in glass flasks of $300 \mathrm{~mL}$ capacity which were constantly agitated. The seeds were cultivated in temperatures of $25 \pm 0.2^{\circ} \mathrm{C}$ in an environment under continuous illumination from compact fluorescent lamps (Empalux, FL 1276 model) of $27 \mathrm{~W}$ and $127 \mathrm{~W}$, in a range of 1300 lux on agitator of 100 rotation/minutes, wrapped with material that blocked the external light. The experiments were

\footnotetext{
1 Analysis of seeds, harvest 2003/2004,Cascavel/PR. Source "Guia de Produtos" COODETEC 2006, p 44 e p 52.
} 
cooled in five replicates of the two cultivars under study and randomly distributed on the agitator. The seeds were kept in culture for eight days and the experiments were three times replicated. The flasks with visible contamination were discarded.

\section{Determination of seeds' fresh weight}

In order to determine the initial fresh weight of the seed, the flasks containing the culture medium were weighed before and after the seeds were inserted. At the end of the experiment, after eight days of cultivation, two or three seeds were removed from the flasks, blotted with a tissue and weighed, in order to obtain the final weight. The fresh weight was determined from the difference of values of final weight in relation to the initial weight.

\section{Determination of protein and oil concentration}

Samples obtained from two or three seeds with the purpose of determining fresh weight as well as the samples of seeds which were still growing in vitro were used to determine the protein and oil seed concentrations. The concentration of oil was determined as described by Pípolo et al. (2004b). The oil content was determined as the mass difference between the initial sample and the powder that remained after the extractions. The oil concentration was expressed with the quantity of oil in $100 \mathrm{mg}$ of the initial sample.

For the nitrogen analysis, the powder that remained in each flask after the oil extraction was analyzed using the Kjeldahl procedure. The samples were digested using a modification of the aluminium block as per Gallear et al. (1975). The catalyst was $1.5 \mathrm{~g}$ of $9: 1 \mathrm{~K}_{2} \mathrm{SO}_{4}$ and the digestion was carried out for at least $4 \mathrm{~h}$ at $375^{\circ} \mathrm{C}$, using 6 $\mathrm{mL}$ of $\mathrm{H}_{2} \mathrm{SO}_{4}$ and $2 \mathrm{~mL}$ of $\mathrm{H}_{2} \mathrm{O}_{2}$. Nitrogen was determined by a semi-automatic colorimetry and the concentration of protein was calculated by multiplying $\mathrm{N}$ concentration by 6.25 .

\section{Statistical analysis}

Randomized blocks in factorial schedule 2X3 (two cultivars and three doses of glutamine) was used for delineation of data. The data for all the measured parameters in each experiment were analyzed using the ANOVA procedure.

\section{RESULTS AND DISCUSSION}

There was no statistical difference of fresh weight gain $(\mathrm{P}>0.05)$ by increasing the glutamine concentrations in the same cultivar (Table 1). Cultivars CD 206 and CD 202 showed an average initial weight of 0.16 and 0.15 , respectively. The comparison of fresh weight gain between the cultivars showed that in the concentration of $20 \mathrm{mM}$, there was no difference, although in 40 and $60 \mathrm{mM}$ concentrations, the accumulation of fresh weight was higher in the CD206 cultivar than in CD 202 cultivar.

To carry out the study, the sucrose concentration was used in $204.49 \mathrm{mM}$ culture medium in order to prevent the precocious germination (Obendorf and Wettlaufer, 1984). Saravitz and Raper (1995) reported (in vitro studies), that the highest fresh weight accumulation was obtained at $150 \mathrm{mM}$ of sucrose, and when sucrose limited the growth, soybean seed was capable of using glutamine as a source of energy source and also as a source of $\mathrm{N}$. In accordance with the results obtained by Pípolo et al. (2004b), the glutamine concentration afftected the composition of soybean seeds. Protein percentage in the seed increased when there was an increase in the glutamine concentration in the cultivation in vitro (Table 2), and there was a statistical difference $(\mathrm{P}<0.05)$ in the same cultivar, which happened in both CD 206 and CD 202 cultivars.

Table 1 - Effect of glutamine concentration on fresh weight gain $(\mathrm{mg})$ of soybean seed grown in vitro during eight days. UEL, Londrina - PR, 2009.

\begin{tabular}{lcccc}
\hline \multirow{2}{*}{ Cultivar } & Inicial weight $^{1}$ & \multicolumn{3}{c}{ in vitro (Glutamine (mM) } \\
\cline { 3 - 5 } & & 20 & 40 & 60 \\
\hline CD 206 & $0.16 \mathrm{Aa}$ & $0.20^{2} \mathrm{Aa}$ & $0.24 \mathrm{Aa}$ & $0.25 \mathrm{Aa}$ \\
$\mathrm{CD} 202$ & $0.15 \mathrm{Ab}$ & $0.19 \mathrm{Aa}$ & $0.19 \mathrm{Ba}$ & $0.20 \mathrm{Ba}$ \\
\hline
\end{tabular}

$\mathrm{CV}(\%)=11.15$
${ }^{1}=$ Seed's average weight in the beginning of development in vitro ${ }^{2}=$ The averages followed by the same letter, uppercase letter in the column and lowercase letter in the line, do not differ from each other, based on the Tukey test $(\mathrm{P}<0,05)$. 
Table 2 - Protein content ${ }^{1}(\%)$ of soybean seeds grown in vitro and in vivo and grown during eight days under different glutamine concentrations. UEL, Londrina - PR, 2009.

\begin{tabular}{lcccc}
\hline \multirow{2}{*}{ Cultivar } & \multirow{2}{*}{ in vivo } & 20 & \multicolumn{3}{c}{ in vitro (Glutamine (mM) } \\
\cline { 2 - 5 } & & $40.97 \mathrm{Ac}$ & 40 & 60 \\
\hline $\mathrm{CD} 206$ & $41.33^{2} \mathrm{Ac}$ & $35.93 \mathrm{Bd}$ & $41.95 \mathrm{Bb}$ & $43.51 \mathrm{Aa}$ \\
$\mathrm{CD} 202$ & $37.09 \mathrm{Bc}$ & & & $42.97 \mathrm{Ba}$ \\
\hline
\end{tabular}

$\mathrm{CV}(\%)=0.59$

${ }^{1}=$ dry basis ${ }^{2}=$ The averages followed by the same letter, uppercase letter in the column and lowercase letter in the line, do not differ from each other, based on the Tukey test $(\mathrm{P}<0,05)$.

The studied cultivars showed relevant statistical differences $(\mathrm{P}<0.05)$ for the cultivation in vitro, since the CD 206 cultivar presented $41.33 \%$ and the CD 202, 37.09\% of protein, a difference of $4.24 \%$ between the two cultivars. There was no statistical difference $(\mathrm{P}>0.05)$ in the $\mathrm{CD} 206$ cultivar cultured in vitro with $20 \mathrm{mM}$ of glutamine concentration. With the same concentration of glutamine, CD 202 cultivar presented a relevant difference, with a low average for the cultivation in vitro (35.93\%) when compared to the cultivation in vivo (37.09\%), therefore, a difference of $1.16 \%$ of protein.

Taking into consideration the gain obtained in protein rates as a result of the cultivation in vitro with 20 and $40 \mathrm{mM}$ glutamine concentrations, it was evident that the increase in protein rate occurred when the glutamine was increased. Nakasathien et al. (2000) suggested that a cultivar with a regular concentration of protein in the seed had a biochemical capability of synthesizing more protein when $\mathrm{N}$ was available. When the cultivars were compared, there was an important statistical difference $(\mathrm{P}<0.05)$ for all the glutamine concentrations in both the cultivations in vitro and in vivo, while the CD 206 cultivar presented the highest averages of protein rates.

Concentration of protein gain of cultivation in vitro with 20 and $40 \mathrm{mM}$ of glutamine concentration was $1.66 \%$ for the cultivar CD 206 and of $6.02 \%$ for the cultivar CD 202. These results showed a major increase in the percentage of protein when the glutamine was increased and a relevant gain in protein concentration of cultivar CD 202. Therefore, there was an important difference between the cultivars in the $20 \mathrm{mM}$ concentration, once the cultivar CD 206 presented 5.04\% more protein than the CD 202 cultivar. In $40 \mathrm{mM}$ concentration, the difference between the cultivars was $0.68 \%$, and the CD 206 cultivar presented a higher value.

Thompson et al. (1977) tested different concentrations of glutamine and the protein reached the maximum value at $62 \mathrm{mM}$. That was also observed in the CD 202 cultivar which showed a tendence to decrease the protein concentration although the same was not observed as regards the cultivar CD 206. Perhaps this behavior would be observed if it was tested with higher concentrations of glutamine. There was a negative relation between the protein and oil (Simpson Junior and Wilcox, 1983; Burton, 1985; Wilcox and Guodong, 1997), although the differences between these two compounds did not show the same variation rates. This showed that different seed's constituents could have been affected due to the availability of $\mathrm{N}$ in the growing medium (Fig. 1). The increase of protein concentration resulted in a decrease of oil concentration (Table 3). The oil concentration of cultivars grown in vivo showed a statistical difference between CD 202 (16.53\%) and CD 206 $(15.55 \%)$. 




Glutamine (mM) concentration In vitro

Figure 1 - Protein and oil content (\%) of soybean seeds cultivated in vivo and in vitro for eight days with variations of glutamine concentrations. UEL, Londrina - PR, 2009. ${ }^{1}=$ Columns followed by the same letter, do not differ from each other, based on the Tukey test $(\mathrm{P}<0.05)$. Uppercase letters compare both cultivars, individually, for the variables of protein and oil. Highlighted lowercase letters compare the protein percentages and regular lowercase letters compare the oil percentages.

Table 3 - Oil content (\%) of soybean seeds developed in vivo and in vitro cultured during eight days with variations of glutamine concentrations. UEL, Londrina - PR, 2009.

\begin{tabular}{lcccc}
\hline \multirow{2}{*}{ Cultivar } & \multirow{2}{*}{ in vivo } & \multicolumn{3}{c}{ in vitro (Glutamine (mM) } \\
\cline { 3 - 5 } & $16.53^{1} \mathrm{Ab}$ & $17.86 \mathrm{Aa}$ & 40 & 60 \\
\hline $\mathrm{CD} 202$ & $15.55 \mathrm{Bab}$ & $15.68 \mathrm{Ba}$ & $15.08 \mathrm{Ac}$ & $14.67 \mathrm{Ad}$ \\
$\mathrm{CD} 206$ & & & $15.23 \mathrm{Ab}$ & $14.24 \mathrm{Bc}$ \\
\hline
\end{tabular}

$\mathrm{CV}(\%)=0.99$

${ }^{1}=$ The averages followed by the same letter, uppercase letter in the column and lowercase letter in the line, do not differ from each other, based on the Tukey test $(\mathrm{P}<0,05)$.

The cultivar CD 206 did not show significant differences $(\mathrm{P}>0.05)$ between the cultivation in vivo $(15.55 \%)$ and the cultivation in vitro at 20 $\mathrm{mM}$ glutamine $(15.68 \%)$, while the cultivar CD 202 cultured in vitro showed relevant differences $(\mathrm{P}<0.05)$ at $20 \mathrm{mM}$ glutamine $(17.86 \%)$ when compared to the cultivation in vivo $(16.53 \%)$. The difference between the cultivars cultured in vitro at $20 \mathrm{mM}$ glutamine was $2.18 \%$.

The gain obtained in oil rates from the cultivation in vitro between 20 and $40 \mathrm{mM}$ of glutamine concentration was $0.45 \%$ for the cultivar 206 and $2.78 \%$ for the cultivar CD 202. There was also a significant difference between the cultivars at 20 $\mathrm{mM}$ concentration, with the CD 206 cultivar showing 2.18\% less oil than the cultivar CD 202. At $40 \mathrm{mM}$ concentration, there was no relevant difference between the two cultivars. In the 60 $\mathrm{mM}$ concentration there was an inversion in the oil rates of the studied seeds. 


\section{CONCLUSION}

With a higher availability of glutamine for the seed, there was an increase of protein content. The genotypes were statistically different as far as the protein concentration was concerned, which confirmed that the genotype had influence on the concentration of protein in the seed.

\section{RESUMO}

Com o objetivo de avaliar a influência do genótipo sobre as concentrações de proteína e óleo, sementes imaturas das cultivares de soja CD 202 e CD 206 foram retiradas da planta mãe no estádio $\mathrm{R}_{5}$, cultivadas in vitro em meio de cultura líquido por oito dias, contendo 20,40 e $60 \mathrm{mM}$ de glutamina. Depois disso, as concentrações de óleo e proteína foram comparadas com as das sementes que continuaram seu desenvolvimento in vivo. Com a maior disponibilidade de glutamina para a semente, houve um aumento do conteúdo protéico nas sementes. Quanto às concentrações de proteína, os genótipos foram estatisticamente diferentes, levando a afirmar a sua influência na concentração de proteína na semente. As concentrações de proteína e óleo foram inversamente relacionadas quando variou a concentração de glutamina.

\section{REFERENCES}

Burton, J.W. (1985), Breeding soybean for improved protein quantity and quality. In: World Soybean Research Conference, III: Proceedings, Ed. R Shibles, Boulder, CO: Westview Press, p. 361-367.

Burton, J.W. (1989), Breeding soybean cultivars for increased seed protein percentage. In: Conferencia Mundial de Invetigacion em Soja IV. Proceedings, Buenos Aires. Actas, Buenos Aires: AASoja, 2, p. 1079-1085

Egli, D.B.; Fraser, J.; Leggett, J.E. and Poneleit, C.G. (1981), Control of seed growth in soya beans [Glycine Max (L.) Merril]. Annals of Botany, London, 48, p. 171-176.

Egli, D.B. and Wardlaw, I.F. (1980), Temperature response of seed growth characteristics of soybeans. Agronomy Journal, Madison, 72, p. 560-564.

Gallear, R.N.; Weldon, C.O. and Futral J.G. (1975), An aluminum block digester for plant and soil analysis. Soil Science Society of America Proceeding, 39, p. 803-806.
Haga, K.L. and Sodek, L. (1987), Utilization of nitrogen sources by immature soybean cotyledons in culture. Annals of Botany, London, 59, p. 597-601.

Hayati, R.; Egli, D.B.; and Crafts-Brandner, S.J. (1996), Independence of nitrogen supply and seed growth in soybean: studies using an in vitro culture system. Journal of Experimental Botany, Oxford, 47, p. 3344.

Holowash, L.P.; Thompson, J.F. and Madison, J.T. (1984), Effects of exogenus methionine on storage protein composition of soybean cotyledons cultured in vitro. Plant Physiology, Maryland, 74, p. 576-584.

Madison, J.T.; Thompson, J.F. and Muenster, A.E. (1981), Turnover of storage protein in seeds of soya bean and pea. Annals of Botany, London, 47, p. 6573.

Marega Filho, M.; Destro, D.; Miranda, L.A.; Spinosa, W.A.; Carrão-Panizzi, M.C. And Montalván, R. (2001), Relationships among oil content, protein content and seed size in soybeans. Braz. arch. biol. technol., Curitiba, 44, P. 23-32.

Nakasathien, S.; Israel, D.W.; Wilson, R.F. and Kwanyuen, P. (2000), Regulation of seed protein concentration in soybean by supra-optimal nitrogen supply. Crop Science, Madison, 40, p. 1277-1284.

Obendorf, R.L. and Wettlaufer, S.H. (1984), Precocious germination during in vitro growth of soybean seeds. Plant Physiology, Maryland, 76, p. 1024-1028.

Oliveira, M.A.R.; Vicente, D.; Dellagostin, M. and Schuster, I. (2004), Introgressão de alto conteúdo de proteína em soja: avaliação em diferentes locais. In: $50^{\circ}$ Congresso Brasileiro de Genética, 2004, Florianópolis. Resumos. Florianópolis: Sociedade Brasileira de Genética, p. 1409.

Pípolo, A.E.; Sinclair, T.R. and Camara, G.M.S. (2004a), Effects of temperature on oil and protein concentration in soybean seeds cultured in vitro. Annals of Applied Biology, 144, p. 71-76.

Pípolo, A.E.; Sinclair, T.R. and Camara, G.M.S. (2004b), Protein and oil concentration of soybean seed cultured in vitro using nutrient solutions of differing glutamine concentration. Annals of Applied Biology, 144, p. 223-227.

Rainbird, R.; Thorne, J.H. and Hardy, R.W.F. (1984), Role of amides, amino acids, and ureides in the nutrition of developing soybean seeds. Plant Physiology, Maryland, 74, p. 329-334.

Saravitz, C.H. and Raper JR, C.D. (1995), Responses to sucrose and glutamine by soybean embryos grown in vitro. Physiologia Plantarum, Copenhagen, 93, p. 799-805.

Simpson JR, A.M. and Wilcox, J.R. (1983), Genetic and phenotypic associations of agronomic characteristics in four high protein soybean populations. Crop Science, Madison, 23, p. 10771081. 
Smith, A.M.; Rinne, R.W. and Self, R.D. (1989), Phosphoenolpyruvate carboxylase and pyruvate kinase involvement in protein and oil biosynthesis during soybean seed development. Crop Science, Madison, 29, 349-353.

Tanaka, R.T.; Mascarenhas, H.A.A.; Regitanod'arce, M.A.B. and Gallo, P.B. (1995), Concentração e produtividade de proteína e óleo de soja em função da adubação potássica e da calagem. Pesquisa Agropecuária Brasileira, Brasília, 30, p. 463-469.

Thompson, J.F.; Madison, J.T. and Muenster, A.E. (1977), In vitro culture of immature cotyledons of soya bean [Glycine max (L.) Merril]. Annals of Botany, London, 41, p. 29-39.

Thompson, J.F.; Madison, J.T.; Waterman, M.A. and Muenster, A.E. (1981), Effec of methionine on growth and protein composition of cultured soybean cotyledons. Phytochemistry, 20, p. 941-945.

Voldeng, H.D.; Cober, E.R.; Hume, D.J.; Gillard, C. and Morrison, M.J. (1997), Fifty-eight years of genetic improvement of short-season soybean cultivars in Canada. Crop Science, Madison, 37, p. 428-431.
Wettlaufer, S.H. and Obendorf, R.L. (1991), Ureides and amides as nitrogen sources for soybean seed growth and maturation in vitro. Crop Science, Madison, 31, p. 1319-1323.

Wilcox, J.R. (1985), Breeding soybean for improved protein quantity and quality. In: World Soybean Research Conference, III: Proceedings. Ed. R Shibles, Boulder, CO: Westview Press, p. 380-386.

Wilcox, J.R. and Guodong, Z. (1997), Relationship between seed yield and seed protein in determinate and indeterminate soybean populations. Crop Science, Madison, 37, p. 361-364.

Received: April 18, 2008; Revised: December 19, 2008; Accepted: October 01, 2009. 